\title{
Evolutionary remnants as widely accessible evidence for evolution: the structure of the argument for application to evolution education
}

\author{
Warren D. Allmon * ${ }^{*}$ and Robert M. Ross
}

\begin{abstract}
Evolution education, in both schools and informal education, often focuses on natural selection and the fit of organisms through natural selection to their environment and way of life. Examples of evidence that evolution has occurred are therefore often limited to a modest number of classic but exotic cases, with little attention to how one might apply principles to more familiar organisms. Many of these classic examples are examples of adaptation; adaptation to local environments is, however, an outcome that could in principle also be explained by supernatural creation or design. A frequent result is the perception among the public is that examples of evolution are rare, and that the existence of well-adapted organisms may just as easily be explained metaphysically. We argue that among categories of evidence of evolution accessible to non-specialists in any environment, the most compelling evidence of common ancestry consists of remnants of evolutionary history evident in homologous features, particularly when those homologies are related to lack of fit of organisms to their way of life ("vestiges") or to better fit that involves complicated combinations of parts usually assigned other functions ("contrivances"). Darwin emphasized the critical nature of this argument from imperfections, and it has been part of traditional catalogs of "evidence for evolution" for more than a century. Yet while remnants of history are widely used as a category of evidence for evolution, their utility in education of comparative anatomy to document body parts passed on through descent is underemphasized in evolution education at all levels. We explore the use of evolutionary remnants to document common ancestry and evidence for evolution, for application to evolution education.
\end{abstract}

Keywords: Homology, Evolutionary remnants, Evidence for evolution, Adaptation, Descent with modification

\section{Introduction}

Amidst the widespread lack of acceptance of evolution among the general public (e.g., Miller et al. 2006; Pew Research Center 2017; Gallup 2017), it is remarkable that polls also report high proportions of respondents agreeing with the statement that there is insufficient scientific evidence for evolution. Surveys of Americans, for instance, find that $20-50 \%$ think that there is abundant credible evidence against evolution, that modern evolutionary theory lacks "a valid scientific foundation," and/

\footnotetext{
*Correspondence: wda1@cornell.edu

Paleontological Research Institution, 1259 Trumansburg Road, Ithaca, NY 14850, USA
}

or that "evolution is far from being proven scientifically" (e.g., Lord and Marino 1993; People for the American Way Foundation 2000; Cunningham and Wescott 2009). As Shtulman (2006) notes, this may not be a deeplyconsidered response, because "those who do not endorse the claim that Darwin's theory of evolution has been well supported by evidence tend to endorse the alternative claim (i.e., that Darwin's theory of evolution has not been well supported by evidence) rather than plead ignorance". Furthermore, lack of knowledge of the evidence for evolution is clearly not necessarily the only, or even the most important, reason for lack of acceptance of evolution (Allmon 2011; Shtulman 2011; Heddy and Nadelson 2012, 2013; Rosengren et al. 2012; Dunk et al. 2017). 
Nevertheless, the idea that there is not much evidence for evolution is so dramatically at variance with the view of virtually all biologists, who essentially see evidence for evolution almost everywhere in nature (e.g., Dobzhansky 1973; Palumbi 2001; Mindell 2006; Dawkins 2009; Vermeij 2010), that it seems worthy of further investigation.

Although many sources over the many years since Darwin have summarized abundant "evidence for evolution" (e.g., Romanes 1882; Heilprin 1888; Ward 1925; Lull 1947; Hotton 1968; Prothero 2007; Coyne 2009; Dawkins 2009; Rogers 2011; Theobald 2012; Mayer 2014; Barnes et al. 2017), there has been surprisingly little explicit discussion of the logic of that evidence and its application to evolution education. As Sober notes: "Given how central the thesis of common ancestry is to evolutionary reasoning, one might expect there to be a vast literature in which the evidence for that claim is amassed. In fact, the question is discussed, but the literature on it is hardly vast" (2008: 264). Textbooks typically present the "evidence for evolution" briefly, describing no more than a few well-documented classic examples from each of five or six categories, including the fossil record, biogeography, genetics, classification, comparative anatomy, and observed small-scale changes. They devote little attention to how students might search for and recognize additional examples of evidence among the organisms they see in local environments, or how examples of these categories complement and strengthen one another. ${ }^{1}$

Providing a better understanding of the nature of evolutionary evidence is important for educators who wish to encourage students and others to explore and learn about evolution "in nature", as opposed or in addition to less open-ended classroom exercises. That is, it is necessary to have a firm understanding of what evolutionary evidence is and how it can be observed in settings that non-scientists are likely to encounter. That is, it is important to find approaches to help students recognize that evidence for evolution is "in their back yards".

\section{What do people intend when they use the word "evolution"?}

It is striking that, as noted recently by Losos (2014: 4), "[e] ven among evolutionary biologists, evolution is defined in different ways". Darwinian evolution is a theory that explains why (i.e., how it came to be that) organisms are the way they are. It consists of three main phenomena: (1) heritable change between generations, resulting mainly (but not exclusively) from natural selection ("descent

\footnotetext{
${ }^{1}$ A recent survey of non-peer-reviewed websites that promote evolution (Barnes et al. 2017) finds that "homology" is the single most frequently used category of empirical evidence for evolution, and that "homology" and "bad design" together comprise $35 \%$ of the empirical evidence presented.
}

with modification", DWM); (2) continuity (lack of change) between generations, resulting from inheritance; and (3) branching, in which multiple descendant lineages are produced from a single ancestral lineage, meaning that all organisms are related and share ancestors in common with one another. The theory says that from these three phenomena come the patterns of diversity, distribution, and adaptation that characterize all living things.

Darwin explicitly considered all three phenomena in On the Origin of Species (1859), although he gave much less attention to branching (discussed in Allmon 2013). In doing so, he set out to convince his readers of two primary points: (1) that organisms have come to be as they are by DWM; and (2) that one particular mechanism, natural selection, is largely responsible for that modification. Importantly, Darwin emphasized that his theory explained both what changes and what does not: the "conditions of existence" of a species lead to change in some features by natural selection, while other features (its "unity of type" of earlier authors) remain unaltered, and therefore can be shared by descendants of a common ancestor (1859: 206).

As is well known, by the time of his death in 1882, Darwin had largely achieved his first goal, at least among knowledgeable people, yet failed in the second; natural selection did not become widely accepted as the major cause of evolutionary change among biologists for another 60 years, and 80 years after the initial publication of The Origin of Species. Yet, once natural selection came to be thought of as the most important mechanism of evolutionary change, during the Modern Evolutionary Synthesis beginning in the 1940s, it became easier to conflate DWM and natural selection, and this continues to the present. ${ }^{2}$ Evolutionary biologists, the media, and creationists alike commonly refer to "evolution" when they really mean natural selection or adaptation, or to "Darwinism" when they really mean DWM, and many summaries of "evidence for evolution" are little more than compilations of examples of adaptation (e.g., Lull 1947; Bellamy and Bellamy 1981; Middleton and Hannibal 2009).

Despite this frequent conflation, the divergent histories of acceptance of DWM and natural selection, as well as

\footnotetext{
${ }^{2}$ This is also noted by Losos (2014: 3). Among creationists, the term "Darwinism" is sometimes used as a synonym for "evolution" (i.e., DWM), at least in part so that they can take advantage of controversies among evolutionary biologists about evolutionary mechanism (e.g., over the adequacy of "Darwinism") (Barnes et al. 2017). For example, in his widely-read book Darwin on Trial (1991), creationist Philip Johnson used the words "Darwinism" and "Darwinist" numerous times; context clearly indicates, however that more than half of these uses referred to DWM, while the rest referred to natural selection. Scott and Branch (2010) discuss use of the term at length.
} 
much other evidence, clearly demonstrate that acceptance of DWM does not require acceptance of natural selection, and that the "fact of evolution" and the mechanisms by which it occurs are conceptually quite separate (Ruse 1979, 1986; Gould 1983; Ospovat 1981a, b; Kampourakis and Zogza 2008: 43; Griffiths 2009; Mayer 2014; Barnes et al. 2017). In this context, the "evidence for evolution" is evidence for DWM.

This means that examples of function or the "fit" of organisms to their environment do not necessarily provide indisputable evidence for DWM. This is because features that are obviously well-suited for their function can, in non-evolutionary world views, also be attributed to other mechanisms, such as an intelligent creator, as in the long tradition of natural theology (Ospovat 1981a, b; Ruse 2003, 2013; see further discussion below). In sum, the implication is that those inclined to be skeptical of evolution because of alternative beliefs may hold the perception that organisms in their local environments are "well-designed," and fail to look for the remnants of DWM and common ancestry among these organisms.

\section{The evidence for DWM}

Historians and biologists both rightly note that one of Darwin's most notable achievements was the synthesis of many categories of seemingly unrelated information, all of which support the hypothesis of DWM (e.g., Mayer 2014). Indeed, it is in part the multiplicity of kinds of evidence (i.e., the wide array of observations that it explains) that makes DWM so convincing (Mayr 2001; Coyne 2009; Rogers 2011). Though he expressed a variety of thoughts on the significance of each category as evidence for evolution, in the Origin Darwin wrote that, of all the categories of evidence, it was "comparative anatomy" that provided the most convincing and abundant evidence for DWM. ${ }^{3}$ That is, patterns of similarities among species ("unity of type") can be explained best by inheritance from a common ancestor. Such observations, wrote Darwin,

"seem to me to proclaim so plainly, that the innumerable species, genera, and families of organic beings, with which this world is peopled, have all descended, each within its own class or group, from common parents, and have all been modified in the course of descent, that I should without hesitation adopt this view, even if it were unsupported by other

\footnotetext{
${ }^{3}$ In 1837 in his first notebook on transmutation, Darwin noted the value of biogeography, and in the very first sentence of the Origin (1859: 1), he implied that it was the evidence of biogeography and the fossil record that convinced him of DWM. Darwin's change from fossils to comparative anatomy has been attributed to his barnacle work [see discussion in Allmon (2016)].
}

\section{facts or arguments" (1859: 457-458).}

The anatomical similarities Darwin was talking about are specifically those that seem to have no apparent function or adaptive value, or to have functions very different from those they were apparently originally built to perform. It was one of Darwin's central insights that such similarities are best explained by DWM, as opposed to some form of supernatural creation. In other words, only in an evolutionary context do such features "make sense" (Dobzhansky 1973; Griffiths 2009). (It may appear at first counterintuitive that Darwin argued that it is lack of change that is the best evidence that change has occurred). In principle, if evidence for DWM through such features observed via comparative anatomy is both abundant and compelling, then it would seem profitable to explore the basis of this approach toward fostering student ability to apply it themselves beyond textbook examples.

Such anatomical features have gone by many names (see discussion of "Terminology", below). Here we refer to them as "evolutionary remnants". When labeled "homologies", they are frequently represented in textbooks by the ubiquitous "vertebrate limb" diagram (Fig. 1) (see, e.g., Thanukos 2008b), and have been pointed to frequently as especially excellent evidence for DWM of humans from other tetrapods (e.g., Wiedersheim 1895; Krogman 1951; Harper 1962; Dodson and Dodson 1985: 213; Gould 1991a; Morgan 1994; Nickels 1998; Novella 2008; Held 2009; Kumala 2010; Lieberman 2011; Werth 2014). Less frequently noted, however, is how numerous they are, not just in humans but in all organisms. As Dobzhansky noted in his famous essay, "[e]xamples of homologies can be multiplied indefinitely" (1973: 128).

The value of homologies as evidence for DWM was championed in modern times especially by Gould (1978a, b, 1985, 1986, 1991b), who cited Darwin as the first to realize that history is best revealed in features of organisms that do not appear to be easily interpretable in terms of their current function (see also Ghiselin 1969). Gould called this approach to historical science-from paleontology to evolution to linguistics - the "panda principle of imperfection", in honor of his favorite example of the "panda's thumb" (1978a, 1980), a modified wrist bone that functions, clumsily, as a sixth digit on this animal's forepaw. He defined the principle as "vestigial organs, [or] odd biogeographic distributions made sensible only as products of history, adaptations as contrivances juryrigged from parts available" (Gould 1986: 64).

While most biological structures may not be as obviously deviant from ideal in their current use, the point is that by learning to recognize evolutionary remnants, students may gain a sense of the high frequency of evidence 


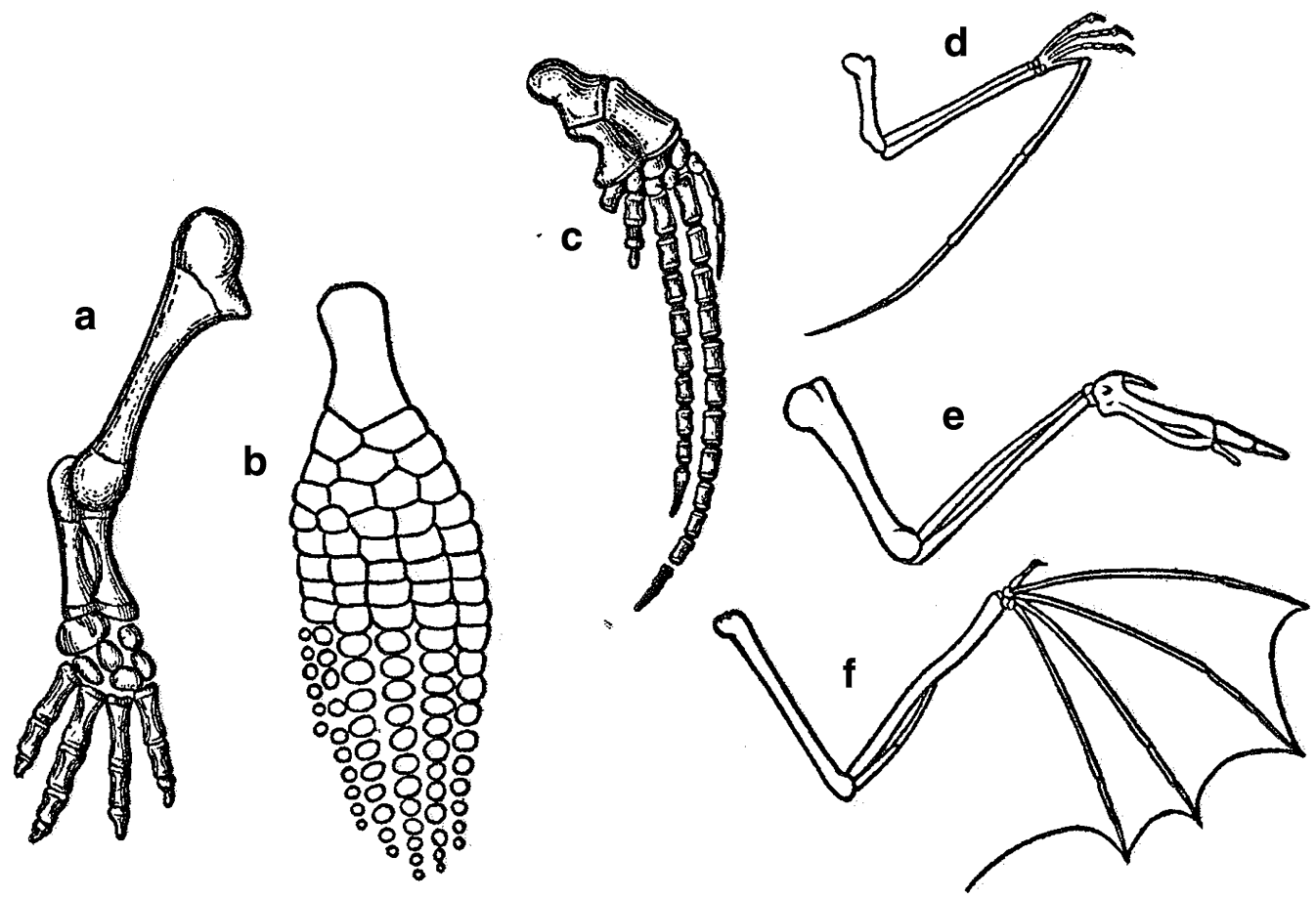

Fig. 1 Vertebrate forelimb homology diagram (from Lull 1947). a Salamander. b Ichthyosaur. c Dolphin. d Pterosaur. e Bird. f Bat

of DWM in nature, a more open-ended opportunity to estimate common ancestry, and a better basis for recognizing evidence for evolution in familiar organisms around them.

Despite this widespread sense among evolutionists that evolutionary remnants observed in homologies provide powerful evidence for DWM, homology itself is in many ways a difficult concept to comprehend, much less to see as compelling evidence for evolution, especially for those such as students who lack extensive biological knowledge. This is for at least three reasons.

1. The full range of functions of a given trait is frequently not evident to non-specialists, let alone whether that trait is being selected for in the local environment or whether it is persisting due to ancestry and/or constraint. For example, it may not be obvious whether having six legs is or is not the "best" possible functional solution for all insects. If one assumes a priori that all creatures are "perfectly" or "optimally" adapted-an idea stemming not only from special creation, but also from widespread and frequently extreme adaptationism within evolutionary biology (e.g., Gould and Lewontin 1979; Orzack and Sober 2001), as well as being embedded in popular culture and implied in the narrative of much public natural history media - then there is no reason to read history into morphology. (Thus, by this reasoning, for example, one would assume that, because all insects have six legs, it must therefore be the case that it is optimal for every insect species to have six legs).

2. Use of the present static condition of something to infer how it changed in the past is an unfamiliar way of thinking to many people and counter to their common experience. The evidence of change with which most people are most comfortable is direct observation (e.g., Thagard and Findlay 2009). Fixed features labeled as "homologies" may therefore be difficult to accept as evidence of evolutionary change, because they do not convey the impression that anything is actually happening, or, by extension, has happened. This is a widespread problem with all evolutionary science, which largely uses static data as evidence of a dynamic process (Lewontin 2002; Forber 2009), and is likely one explanation for the common objection from creationists that we cannot "see evolution happen" (e.g., Morris and Morris 1996: 57; Perloff 1999: 116).

3. As emphasized by Gilbert (2003: 735), "homology can be a tricky concept... [because] it risks forming a circular argument wherein structures are considered homologous because of common origin, and these animals are said to have a common origin because 
they have homologous structures. An independent assessment of ancestry and origins is needed". Thus, it is important to help students recognize that diverse independent evidence gives us confidence that DWM has occurred and that comparative anatomy is an effective tool to find evidence of common ancestry in organisms around us.

\section{Terminology}

Despite 150 years of discussion, the terminology of these organismal features remains confused (Table 1). Darwin referred to features of organisms that appear to point to their evolutionary history as "Rudimentary, atrophied, or aborted organs" (1859: 450), writing that

"Organs, however little developed, if of use, should not be called rudimentary; they cannot properly be said to be in an atrophied condition; they may be called nascent, and may hereafter be developed to any extent by natural selection. Rudimentary organs, on the other hand, are essentially useless, as teeth which never cut through the gums..." (1859: 452).

He also called them "vestigial" or "vestiges", once each in the first edition of the Origin (1859: 453, 454). As pointed out by Sober (2008: 297), these particular terms carried "the double meaning that Darwin intended: vestigial traits are useless to the organism and they are vestiges of a bygone age. By recognizing that they are useless, we see that they provide substantial information about the past" (emphasis added). Such vestiges can range from trait degeneration to full trait loss (Johnson et al. 2012). Coyne (2009: 55), however, suggests that "Evolutionary theory doesn't say that vestigial characteristics have no function. A trait can be vestigial and functional at the same time. It is vestigial not because it is functionless, but because it no longer performs the function for which it evolved" (emphasis in original; see also Griffiths
1992, 2009; Senter 2010). Werth (2014) provided a more comprehensive usage: vestiges are features that appear to have no function, or which currently serve a function in a suboptimal or compromised way, or a function different from that which they previously served.

With or without obvious or demonstrable function, features in common among organisms can be referred to simply as "homologies", in the sense of being similarities due to shared inheritance of developmental programs from a common ancestor (Futuyma 2009: 560; see also Mayer 2014). Unfortunately, in addition to the complexities with which the term "homology" is historically fraught (e.g., De Beer 1971; Hall 1994, 2003; Mindell and Meyer 2001; Wagner 2002; Brigandt and Griffiths 2007; Rieppel and Kearney 2007; McCune and Schimenti 2012; Baum, 2013; Minelli and Fusco 2013), this definition has the weakness of being tautological if we are seeking to use particular features as evidence for common ancestry (Gilbert 2003; Griffiths 2007). In this context, DWM is the explanation for homology, not its definition. A variety of other definitions of homology run aground on the increasingly common observations that many homologous features are derived from different genes and/or different embryological/developmental pathways (Hall 1994; Shubin et al. 2009; but see Baum 2013). Thus, many modern evolutionists revert to a very simple definition of homology: "structural and positional similarity... the same organ in different animals under a variety of form and function" (Panchen 1994: 56).

Darwin informally used the term "contrivances" for complicated structures made of multiple functioning parts (especially Darwin 1862). His use was primarily descriptive, but through his work it has taken on the connotation of a structure made through modification of existing anatomical parts:

"Orchids exhibit an almost endless diversity of beautiful adaptations. When this or that part has been

\section{Table 1 Various terms for features in organisms that appear to point to descent with modification}

\begin{tabular}{ll}
\hline Term & Reference \\
\hline Rudimentary, atrophied, or aborted organs, atavisms & Darwin (1859); Hall (2010) \\
Vestiges/vestigial organs & Darwin (1859); Werth (2014) \\
Scars & Krogman (1951); Morgan (1994) \\
Senseless signs of history & Gould (1978b) \\
Exaptations & Gould and Vrba (1982); Vrba (2002) \\
Imperfections and oddities & Gould (1986); Margulis et al. (2005) \\
Palimpsests & Weiss and Kawasaki (2006); Morange (2008); Coyne (2009); Mayer (2009) \\
Remnants of evolution & Spinney (2008) \\
Contrivances & Darwin (1862) \\
Traces of common descent & Rogers (2011) \\
\hline
\end{tabular}


spoken of as contrived for some special purpose, it must not be supposed that it was originally always formed for this sole purpose. The regular course of events seems to be, that a part which originally served for one purpose, by slow changes becomes adapted for widely different purposes." (1862: 346)

Thus structures may be effective from the perspective of fitness, but develop using remnant homologous anatomical elements used for other functions in related organisms.

Authors have thus referred to such features that retain historical information by a variety of names (Table 1), each of which has slightly different usage and implications and communicates a certain kind of information about evolutionary history. There does not, however, appear to be a widely accepted, appropriate term for the historical traces represented in homologies that is neutral with respect to current fitness or function. We have chosen to use the existing term "evolutionary remnants" for such features. Conceptually, every homology contains both historical remnants (aspects in common with the homologous structure of the ancestral species and possibly that of other species that share a common ancestor) and modifications (through adaptation or other process). Evolutionary remnants in this sense include conserved character states that are the basis for determining systematic relationships. Terms such as vestige, contrivance, oddity, and imperfection are special instances of evolutionary remnants that are especially compelling because we have evidence that function in a given case is suboptimally or inefficiently developed, consistent with DWM but inconsistent with Special Creation. Not all observable remnants of evolutionary history, however, including many that may be found among local organisms, can be readily fit by novices (such as students) into these categories; in isolation, and without additional context, it will not be evident to students whether bird wings, whale flippers, or nearly any other biological structure is a contrivance or perfectly designed. It may be possible, in contrast, without deep biological knowledge, to recognize that consistency in anatomical structures among organisms with widely different life modes (including highly functional anatomical units such as limbs adapted to flying or swimming), and, conversely, lack of consistency among organisms with the same life modes, are most easily explained by DWM.

Moreover, evolutionary remnants, including vestiges and contrivances, constitute excellent evidence for DWM in part because the characters of organisms are not scattered randomly, but rather are arranged in such a pattern that implies (i.e., requires for its explanation) a hierarchical, branching tree and change through time. As noted by Rogers (2011), such "[p]hylogenetic pattern is everywhere in nature", and "makes sense only if all living things evolved from a single ancestor" (p. 31). This is the simplest possible version of "tree thinking" (e.g., Gregory 2008; Meisel 2010; Baum and Smith 2013). If species had been independently created as we see them, there would be no reason to expect characters to be arranged in such a pattern, one that implies a phylogenetic tree, yet this is what we find everywhere in the biological world.

The reason we do not think that such "phylogenetic" patterns are caused by the observed features being "simply the best way to do the job and were thus selected for this job by the creator", is that we also see traces of common descent at finer and finer scales; closely related species share more history and thus have a larger number of similar evolutionary remnants, while distant relatives share fewer evolutionary remnants or those that are similar in a more generalized way; these patterns are then overlain by a nested pattern of similarities, which is indicative of common descent (Rogers 2011: 43-44). The reason that "nothing in biology makes sense except in the light of evolution" (Dobzhansky 1973) is because "[w]ithout evolution, biology is a huge mass of unconnected facts. Evolution is a lens that makes those facts jump sharply into focus. The real power of evolution to convince lies in the huge mass of facts that it manages to so simply explain..." (Rogers 2011: 100).

\section{Inferences from historical remnants}

This line of reasoning, however, invites a more fundamental question: how do we really know that homologous structures are "the same", or that remnants once served a different function? (see Minelli and Fusco 2013 for a recent thorough review.) This question is in turn just a special case of the general problem of historical inference. It is self-evident that historians (of human history) cannot recreate or directly experiment on the past to test their hypotheses. The only evidence available to them is therefore traces of the past (e.g., Langlois and Seignobos 1898: 63-64; Vincent 1911: 122; Elton 2002: 54) or, as one historiographer puts it, "not 'fact' but testimony on the facts" (Shafer 1974: 4). Yet how can one have confidence that the past leaves behind such traces or testimony? We think it is pedagogically useful to compare applications of this approach to human and non-human examples.

Historical remnants applied to human history: Human historians have also long understood that this is a general principle of historical reasoning, from fashion to language to technology. For example:

"The ridiculous little tails of the German postilion's coat show of themselves how they came to dwindle to such absurd rudiments; but the English clergyman's 
bands no longer so convey their history to the eye, and look unaccountable enough til one has seen the intermediate stages, through which they came down from the more serviceable wide collars... The books of costume show how one garment grew or shrank by gradual stages and passed into another." (Tylor 1889: 17ff; quoted in Randall 1958: 68)

Applications in which the "panda principle" has been applied (by name) include the history of technology (e.g., typewriter keyboards (Gould 1991a, b), and the dominance of the Windows ${ }^{\circledR}$ operating system for personal computers [http://ozone.wordpress.com/2006/04/05/ the-panda-principle]; see also Larson et al. 2013). This principle is also the basis for modern forensic science (e.g., Nickell and Fischer 1999; Houck and Siegel 2010), in which the "vestige" is the evidence of the crime. Such examples provide useful intuitive analogs for helping nonspecialists see the use of historical remnants in recognizing and reconstructing history, as a bridge to similar historical thinking in biology.

Darwin himself looked beyond biology, noting the similarity between the search for the origin of words in historical linguistics and the origin of particular features of living organisms: "Rudimentary organs may be compared with the letters in a word, still retained in the spelling, but become useless in the pronunciation, but which serve as a clue in seeking for its derivation" (1859: 456). More generally, etymological roots are remnants passed on through word evolution, words continue to be among the best non-biological examples of evidence for DWM (van Wyhe 2005; Thanukos 2008a).

Prior to the Enlightenment, scholars imagined that words and languages had been created as they were, via divine agency (van Wyhe 2005: 94). A slightly more "historical" interpretation of word origins-more closely analogous to evolutionary adaptation-was that they owe their origins to "functional" connections between the word and the thing to which the word refers (e.g., Lass 1990, 1997; Lieberman 2006), such as words based on the onomatopoetic resemblance of sounds (e.g., " $g r-g r$ " represents the sound of "grinding" in many languages), or on the physical resemblance of one thing to another. The word daisy, for example, is derived from Old English words meaning "day's eye" - "either because the daisy resembles the sun... or because it covers the yellow disk in the evening and opens it in the morning" (Lieberman 2006: 7-8). Although such words may not originate by a process akin to natural selection (i.e., variation, overproduction, etc.), they are explicable in much the same ways as are adaptations in organisms-because they obviously originated in response to an aspect of their current "function".
Yet clearly not all word origins have such relatively straightforward explanations (van Wyhe 2005). For example, many things are called differently in different languages, and the same groups of sounds have different meanings within a language (i.e., homonyms). Most conspicuously, many words are clearly not directly derived from their current use (Rankin 2003; Lieberman 2006), but rather are "jury-rigged", a term which itself demonstrates the phenomenon it names. The expression refers to makeshift repairs or temporary contrivances, made with only the tools and materials that happen to be on hand. It was originally a nautical term; on a sailing ship, a "jury rig" was a replacement mast and yardarm improvised in case of damage or loss of the original mast (Onions 1966: 637). ${ }^{4}$

Darwin's use of remnants in recognizing traces of evolutionary history: Darwin's key insight about such features was that if organisms have a history of change-of DWM - then that history will inevitably leave traces or remnants. These can be recognized, Darwin suggested, in features that do not appear well-suited to their present function or to have any function at all. "Organs or parts in this strange condition," he wrote, "bearing the stamp of inutility, are extremely common throughout nature" (1859: 450). The existence of such structures, "organs in a rudimentary, imperfect, and useless condition, or quite aborted, far from presenting a strange difficulty, as they assuredly do on the ordinary doctrine of creation, might even have been anticipated, and can be accounted for by the laws of inheritance" (1859: 456). Crucially, Darwin then extended this insight:

\section{"On this same view of descent with modification, all the great facts in Morphology become intelligible,- whether we look to the same pattern displayed in the homologous organs, to whatever purpose applied, of the different species of a class; or to the homologous parts constructed on the same pattern in each indi- vidual animal and plant" (1859: 457).}

When exactly Darwin came to his insight about the theoretical importance of homologous structures as evidence for common ancestry and DWM is not clear. In his "B" notebook, written between July, 1837 and January 1838 , he wrote: "When one sees nipple on man's breast. One does not say some use $[$ sic]... so with useless wings under elytra of beetles.-born from beetles with wings \& modified.-if simple creation, surely would

\footnotetext{
${ }^{4}$ There are in turn several theories about the origin of this usage of "jury". It may be from the Latin adjutare ("to aid") via Old French ajurie ("help or relief") (Barnhart 1988: 560); or it may be a corruption of "joury mast", a mast for the day (from the French, jour, a day), i.e., a temporary mast (Brewer 1898).
} 
have been born without them" (Barrett et al. 1987: 192). In his unpublished sketch of 1844, Darwin said of "abortive or rudimentary organs" that "On the ordinary view of individual creations, I think that scarcely any class of facts in natural history are more wonderful or less capable of receiving explanation" (Darwin 1909a, b: 233). As evidence for the importance Darwin attributed to this principle, Gould (1986) noted that Darwin's next book after the Origin focused on how the multitude of structures that orchids use to effect pollination are all modifications of common components of "ordinary" flowers, parts usually used for very different functions (Darwin 1862, 1877).

\section{Design as an explanation for patterns of similarity}

In teaching that the ubiquitous presence of evolutionary remnants is an indicator of history, we must consider the nature of student reasoning that incorporates metaphysical non-historical alternatives. Confronted with evolutionary remnants, a non-evolutionist may argue, for example, (1) that their function has yet to be adequately understood; (2) for a principle of "limited perfection" (that a creator never intended them to be perfect in every way; see further discussion below); (3) that such features represent expressions of the unintelligible thoughts of a creator, or some kind of underlying "archetype" (Owen 1848; Ospovat 1981a, b; Desmond 1986); or (4) that such features are a consequence, due to the Fall (described in Genesis of the Bible), of degeneration of the created design. What all of these have in common is that they do not require or imply any actual history or change through time. As Darwin wrote in the Origin: "On the ordinary view of the independent creation of each being, we can only say that so it is-that it has so pleased the Creator to construct each animal and plant" (1859: 435).

Features that are of obvious use and function can, in a non-evolutionary world view, be attributed to an intelligent creator, but non-evolutionary views offer only limited possible explanations for features of organisms that do not "make sense" in terms of their current function. Coyne (2009) wrote: "The evolutionary argument is that these imperfections and inefficiencies make sense only if one assumes that evolution has occurred!" (2009: 9).

This has been labeled "incompetent design" by Wise (2005) and the "no-designer-worth-his-salt objection to the hypothesis of intelligent design" (Radick 2005; Sober 2008). Importantly, however, it has been criticized, by both creationists and evolutionists, because it appears to assume knowledge of what such a designer wanted to achieve (e.g., Nelson 1996; Bergman 2001, 2003; Brown 2010: 732). As Darwin himself asked: "Have we any right to assume that the Creator works by intellectual powers like those of man?" (1859: 188). For example, Sober points out that Gould's "Panda Principle" assumes

"that an intelligent designer would have wanted to supply pandas with a super-efficient device... for preparing bamboo and would have had the ability to achieve this objective. But why is it so clear that God would have wanted to do this?... Creationists don't need to assert that they know what God would have had in mind if he had built the panda. All they need to say is that Gould does not know this" (Sober 2008: 127-128; emphasis in original).

Comparing "evolution" to "creation" is in general difficult or impossible because of the lack of any observable predictions from the "hypothesis" of supernatural or intelligent design (Kitcher 1993; Pennock 1999; Shanks 2004; Sober 2008; Baum et al. 2016). We can, however, contrast the two kinds of explanations in order to stimulate deeper thinking when asking why something looks the way it does. As Futuyma (1998) puts it, using the familiar vertebrate forelimb example (Fig. 1), the design hypothesis "does not require that the same bony elements form the frame of the hands of primates, the digging forelimbs of moles, the wings of bats, birds, and pterosaurs, and the flippers of whales and penguins." In contrast, DWM

\section{"explains why the stings of wasps and bees are modified ovipositors, and why only females possess them... Homologous characters include features that appear during development, but would not be neces- sary if the development of an organism were not a modification of its ancestor's ontogeny. For example, tooth primordia appear and then are lost in the jaws of fetal anteaters..." (Futuyma 1998: 122; emphasis added).}

As discussed above, history does require (i.e., it almost inevitably results in) the persistence of traces of previous states. ${ }^{5}$ Therefore, we do not need to speculate about the unknowable motivations of a possible divine creator to make predictions about what we would expect to see if DWM is true. If our observations match these predictions, then we can conclude that DWM is more probable than the alternative.

\footnotetext{
5 The persistence of such traces is not, in fact, absolutely inevitable. In principle, all traces of history could be erased by subsequent changes. In practice, however, almost all historical systems are sufficiently complex that it is statistically extremely unlikely that all of their elements will change, and therefore extremely likely that at least some traces of previous condition will remain.
} 


\section{Implications for evolution education}

The most compelling argument for interpreting homologous similarities as evidence of evolution is that they are the inevitable traces of historical change. These traces demonstrate that the process by which living things have come to look as they do necessarily results in their possessing features that indicate the pattern of their historical genealogical relationships. Thus, just as natural selection is an inevitable result of the phenomena of the combination of reproduction, variation, inheritance, and resource limitation, evolutionary remnants are the inevitable phenotypic and genotypic results of the phenomenon of DWM. Evidence of evolution is not rare, or especially difficult to find or see; on the contrary, by its very nature, evolution leaves an abundant and-once you know what you're looking for-conspicuous evidentiary record which can be seen in our own back yards.

An effective evolution education approach may therefore focus on providing students conceptual tools to evaluate this evidentiary record in their own environment. These tools include the common observations that (1) all organisms possess features that share with other organisms, some of which do not appear to have a current function, or which serve a function in a clearly compromised, contrived, or less-than-optimal way, and (2) such features are not scattered randomly, but rather are arranged universally in such a pattern that implies (i.e., requires for its explanation) a hierarchical, branching tree. These patterns can be observed-with some minimal knowledge of natural history-in any natural setting that contains organisms that share evident homologous traits.

Locally applied versions of an evolution education curriculum that follow this line of thinking would accordingly seek as a goal that students discover that evidence for evolutionary history is in organisms all around them, and make historical inferences from available observations. At small scales, upper-level college biology courses have long existed that focus on this approach, but such courses can depend heavily on the expertise of a few faculty, prior knowledge of advanced biology students, and college-based access to equipment and resources.

Expanding the approach beyond such relatively advanced experiences has at least three minimal requirements. First is choice of specific taxonomic groups for which appropriate specimens are readily available, either through collection in the field (e.g., vascular plant leaves) or purchase (e.g., vertebrate skull casts). Second is sufficient familiarity with these taxa on the part of the instructor, and/or the availability of teacher-friendly resources and/or professional development on their comparative anatomy. Third, and most importantly, it requires educators to adopt a relatively flexible and open-ended approach to teaching. Such an approach is consistent with all three dimensions of the Next Generation Science Standards, being adopted or adapted in most states of the US-that is, not only content on evolution (Disciplinary Core Ideas), but Science and Engineering Practices and Cross-Cutting Concepts (NGSS 2013). More generally, such an approach must include willingness to see evolutionary biology as, in part, the open-ended exploration of the traditional questions of natural history (cf., Greene 1986): what are the patterns of similarity and difference among organisms, and how did they most probably come about?

\section{Authors' contributions \\ WDA and RMR conceived of the approach together. WDA wrote the initial draft of the manuscript, after which RMR made revisions. Both authors read and approved the final manuscript.}

\section{Acknowledgements}

We are grateful to Dana Friend, Andrielle Swaby, and Jason Wiles for discussion, to Amanda Schmitt for editorial assistance, and to Kim Sterelny, several anonymous reviewers, and especially David Baum for comments on previous drafts

\section{Competing interests}

The authors declare that they have no competing interests.

Ethics approval and consent to participate Not applicable.

\section{Publisher's Note}

Springer Nature remains neutral with regard to jurisdictional claims in published maps and institutional affiliations.

Received: 5 January 2017 Accepted: 5 December 2017

Published online: 09 January 2018

\section{References}

Allmon WD. Why don't people think evolution is true? Implications for teaching, in and out of the classroom. Evol Educ Outreach. 2011;4:648-65. https://doi.org/10.1007/s12052-011-0371-0.

Allmon WD. Species, speciation, and paleontology up to the modern synthesis: persistent themes and unanswered questions. Palaeontology. 2013:56(6):1199-223.

Allmon WD. Darwin and paleontology: a re-evaluation of his interpretation of the fossil record. Hist Biol. 2016;28(5):680-706 (published online 2015).

Barnes RM, Church RA, Draznin-Nagy S. The nature of the arguments for creationism, intelligent design, and evolution. Sci Educ. 2017;26:27-47.

Barnhart RK. Barnhart dictionary of etymology. New York: H.W. Wilson; 1988.

Barrett PH, Gautrey PJ, Herbert S, Kohn D, Smith S. Charles Darwin's notebooks, 1836-1844. Ithaca: Cornell University Press; 1987

Baum DA. Developmental causation and the problem of homology. Philos Theory Pract Biol. 2013;5:e403.

Baum DA, Smith SD. Tree thinking: an introduction to phylogenetic biology. Greenwood Village: Roberts and Company; 2013.

Baum DA, Ané C, Larget B, Solís-Lemus C, Ho LST, Boone P, Drummond CP, Bontrager M, Hunter SJ, Saucier W. Statistical evidence for common ancestry: application to primates. Evolution. 2016;70:1354-63.

Bellamy DJ, Bellamy TJ. Bellamy's backyard safari. A primer to the study of evolution, right in your own back yard. London: British Broadcasting Corporation; 1981. 
Bergman J. Does homology provide evidence of evolutionary naturalism. Creation ex Nihilo Technical Journal (TJ; now J Creat). 2001;15(1):26-33.

Bergman J. Why the 'poor design'argument against intelligent design is unsound. Creation ex Nihilo Technical Journal (TJ; now J Creat). 2003;17(3):113-8.

Brewer EC. Dictionary of phrase and fable. Philadelphia: Henry Altemus; 1898 Brigandt I, Griffiths PE. The importance of homology for biology and philosophy. Biol Philos. 2007;22:633-41.

Brown CM. Hindu responses to Darwinism: assimilation and rejection in a colonial and post-colonial context. Sci Educ. 2010;19:705-38.

Coyne J. Why evolution is true. New York: Viking: 2009.

Cunningham DL, Wescott DJ. Still more "fancy" and "myth" than "facts" in students' conceptions of evolution. Evol Educ Outreach. 2009;2(3):505-17.

Darwin C. On the origin of species. London: John Murray; 1859

Darwin C. On the various contrivances by which British and foreign orchids are fertilized by insects, and the good effects of intercrossing. London: John Murray; 1862.

Darwin C. The various contrivances by which orchids are fertilized by insects. London: John Murray; 1877.

Darwin C. The foundations of the origin of species. Two essays written in 1842 and 1844. Cambridge: Cambridge University Press; 1909a.

Darwin F. Introduction. In: Darwin F, editor. The foundations of the origin of species. Two essays written in 1842 and 1844 by Charles Darwin. Cambridge: Cambridge University Press; 1909b. p. xi-xxix.

Dawkins R. The greatest show on earth: the evidence for evolution. New York: Free Press; 2009.

De Beer G. Homology, an unsolved problem (Oxford Biology Readers). London: Oxford University Press; 1971.

Desmond A. Archetypes and ancestors. Chicago: University Chicago Press; 1986.

Dobzhansky T. Nothing in biology makes sense except in light of evolution. Am Biol Teach. 1973;35(3):125-9.

Dodson EO, Dodson P. Evolution. Process and product. 3rd ed. Belmont:Wadsworth Publishing Co.; 1985.

Dunk RDP, Petto AJ, Wiles JR, Campbell BC. A multifactorial analysis of acceptance of evolution. Evol Educ Outreach. 2017;10:4. https://doi. org/10.1186/s12052-017-0068-0.

Elton GR. The practice of history. 2nd ed. Oxford: Blackwell; 2002

Forber P. Spandrels and a pervasive problem of evidence. Biol Philos. 2009;24(2):247-66.

Futuyma DJ. Evolutionary biology. 3rd ed. Sunderland: Sinauer Associates; 1998

Futuyma DJ. Evolution. 2nd ed. Sunderland: Sinauer Associates; 2009.

Gallup. In U.S., belief in creationist view of humans at new low. 2017. http:// news.gallup.com/poll/210956/belief-creationist-view-humans-newlow.aspx. Accessed 22 Nov 2017

Ghiselin MT. The triumph of the Darwinian method. Berkeley: University California Press; 1969.

Gilbert SF. Opening Darwin's black box: teaching evolution through developmental genetics. Nat Rev Genet. 2003;4(9):735-41.

Gould SJ. The panda's peculiar thumb. Nat Hist. 1978a:87(9):20-30

Gould SJ. Senseless signs of history. Nat Hist. 1978b;87(10):22-8.

Gould SJ. The panda's thumb: more reflections in natural history. New York: WW Norton; 1980

Gould SJ. Evolution as fact and theory. In: Gould SJ, editor. Hen's teeth and horse's toes. New York: WW Norton; 1983. p. 253-62 (Original work published 1981)

Gould SJ. Adam's navel. In: Gould SJ, editor. The flamingo's smile. New York: WW Norton; 1985. p. 99-113 (Original work published 1984).

Gould SJ. Evolution and the triumph of homology, or why history matters. Am Sci. 1986;74(1):60-9.

Gould SJ. Freudian slip. In: Gould SJ, editor. Bully for Brontosaurus. New York: WW Norton; 1991a. p. 124-38 (Original work published 1987)

Gould SJ. The panda's thumb of technology. In: Gould SJ, editor. Bully for Brontosaurus. New York: WW Norton; 1991 b. p. 59-75 (Original work published 1987)

Gould SJ, Lewontin RC. The spandrels of San Marco and the Panglossian paradigm: a critique of the adaptationist programme. Proc R Soc Lond B. 1979;205:581-98

Gould SJ, Vrba ES. Exaptation — a missing term in the science of form. Paleobiology. 1982;8(1):4-15.
Greene HW. Natural history and evolutionary biology. In: Feder ME, Lauder GV, editors. Predator-prey relationships. Perspectives and approaches from the study of lower vertebrates. Chicago: University of Chicago Press; 1986. p. 99-108.

Gregory TR. Understanding evolutionary trees. Evol Educ Outreach. 2008;1 (2):121-37.

Griffiths P. Adaptive explanation and the concept of a vestige. In: Griffiths P, editor. Trees of life. Dordrecht: Kluwer Academic Publishers; 1992. p. $111-31$.

Griffiths P. The phenomena of homology. Biol Philos. 2007;22(5):643-58.

Griffiths P. In what sense does "nothing make sense except in the light of evolution". Acta Biotheor. 2009;57:11-32.

Hall BK, editor. Homology: the hierarchical basis of comparative biology. San Diego: Academic Press; 1994.

Hall BK. Descent with modification: the unity underlying homology and homoplasy as seen through an analysis of development and evolution. Biol Rev. 2003;78(3):409-33.

Hall BK. Atavisms. Curr Biol. 2010;20(20):R871.

Harper RMJ. Evolution and illness: a short essay on the clinical significance of evolutionary vestiges. Edinburgh: E\&S Livingstone Ltd; 1962.

Heddy BJ, Nadelson LS. A global perspective of the variables associated with acceptance of evolution. Evol Educ Outreach. 2012;5(3):412-8.

Heddy BJ, Nadelson LS. The variables related to public acceptance of evolution in the United States. Evol Educ Outreach. 2013;6(1):1-14.

Heilprin A. The geological evidences for evolution. Philadelphia: Self-published; 1888.

Held LI Jr. Quirks of human anatomy: an evo-devo look at the human body. Cambridge: Cambridge University Press; 2009.

Hotton N III. The evidence of evolution. Washington, DC: American Heritage, Smithsonian Institution; 1968

Houck MM, Siegel JA. Fundamentals of forensic science. 2nd ed. Waltham: Academic Press; 2010

Johnson PE. Darwin on trial. Washington, DC: Regnery Gateway; 1991.

Johnson NA, Lahti DC, Blumstein DT. Combating the assumption of evolutionary progress: lessons from the decay and loss of traits. Evol Educ Outreach. 2012;5:128-38.

Kampourakis K, Zogza V. Students' intuitive explanations of the causes of homologies and adaptations. Sci Educ. 2008;17:27-47.

Kampourakis K, Zogza V. Preliminary evolutionary explanations: a basic framework for conceptual change and explanatory coherence in evolution. Sci Educ. 2009;18:1313-40.

Kitcher P (1993) The advancement of science. Science without legend, objectivity without illusions. New York: Oxford University Press.

Krajcik JS. Learning science by doing science. In: Yager R, editor. What research says to the science teacher: STS in the classroom. Washington, DC: National Science Teachers Association; 1993. p. 53-8.

Krogman WM. The scars of human evolution. Sci Am. 1951;185(6):54-7.

Kumala M. A natural history of you. Evol Educ Outreach. 2010;3(4):532-8.

Langlois CV, Seignobos C. Introduction to the study of history. New York: Henry Holt; 1898.

Larson G, Stephens PA, Tehrani JJ, Layton RH. Exapting exaptation. Trends Ecol Evol. 2013;28(9):497-8.

Lass R. How to do things with junk: exaptation in language evolution. J Linguist. 1990;26:79-102.

Lass R. Historical linguistics and language change. Cambridge: Cambridge University Press; 1997.

Lehrer R, Schauble L. Seeding evolutionary thinking by engaging children in modeling its foundations. Sci Educ. 2012;96:701-24.

Lewontin RC. Directions in evolutionary biology. Annu Rev Genet. 2002;36:1-18.

Lieberman P. Toward an evolutionary biology of language. Cambridge: Harvard University Press; 2006.

Lieberman DE. The evolution of the human head. Cambridge: Harvard University Press; 2011.

Lombrozo T, Thanukos A, Weisberg M. The importance of understanding the nature of science for accepting evolution. Evol Educ Outreach. 2008; 1:290-8

Lord T, Marino S. How university students view the theory of evolution. J Coll Sci Teach. 1993;22(6):353-7.

Losos JB. What is evolution. In: Losos JB, editor. The Princeton guide to evolution. Princeton: Princeton University Press; 2014. p. 3-9. 
Lull RS. Organic evolution. Revised edition. New York: Macmillan; 1947.

Margulis L, Dolan MF, Whiteside JH. "Imperfections and oddities" in the origin of the nucleus. Paleobiology. 2005;31(2):175-91.

Mayer GC. The palimpsest theory. 2009. https://whyevolutionistrue.wordpress. com/2009/03/08/the-palimpsest-theory/. Accessed 12 June 2013.

Mayer GC. The evidence for evolution. In: Losos JB, editor. The Princeton guide to evolution. Princeton: Princeton University Press; 2014. p. 28-39.

Mayr E. What evolution is. New York: Basic Books; 2001

McCune AR, Schimenti JC. Using genetic networks and homology to understand the evolution of phenotypic traits. Curr Genom. 2012;13:74-84.

Meisel RP. Teaching tree-thinking to undergraduate biology students. Evol Educ Outreach. 2010;3(4):621-8.

Middleton S, Hannibal ME. Evidence of evolution. New York: Abrams; 2009

Miller JD, Scott EC, Okamoto S. Public acceptance of evolution. Science. 2006;313:765-6.

Mindell DP. The evolving world: evolution in everyday life. Cambridge: Harvard University Press; 2006

Mindell DP, Meyer A. Homology evolving. Trends Ecol Evol. 2001;16(8):434-40.

Minelli A, Fusco G. Homology. In: Kampourakis K, editor. The philosophy of biology: a companion for educators. Netherlands: Dordrecht; 2013. p. 289-322.

Moore JA. Science as a way of knowing: the foundations of modern biology. Cambridge: Harvard University Press; 1993.

Morange M. Life explained. New Haven: Yale University Press; 2008.

Morgan E. Scars of evolution. New York: Oxford University Press; 1994.

Morris HM, Morris JD. Science and creationism, vol. 2 of The modern creation trilogy. Green Forest: Master Books; 1996.

Müller GB. Vestigial organs and structures. In: Pagel M, editor. Encyclopedia of evolution. Oxford: Oxford University Press; 2002. p. 1131-3.

Nelson P. The role of theology in current evolutionary reasoning. Biol Philos. 1996:11(4):493-517.

NGSS Lead States. Next generation science standards: for states, by states. Washington, DC: The National Academies Press; 2013

Nickell J, Fischer JF. Crime science: methods of forensic detection. Lexington: University Kentucky Press; 1999.

Nickels M. Humans as a case study for the evidence of evolution. Rep Natl Cent Sci Educ. 1998;18(5):24-7.

Novella S. Suboptimal optics: vision problems as scars of evolutionary history. Evol Educ Outreach. 2008;1(4):493-7.

Numbers RL. The creationists. from scientific creationism to intelligent design. Expanded ed. Cambridge: Harvard University Press; 2006

Onions CT (editor). Jury rig. In: The Oxford english dictionary. vol. V. Oxford: Clarendon Press (Originally printed 1933); 1966. p. 637.

Orzack SH, Sober E. Introduction. In: Orzack SH, Sober E, editors. Adaptationism and optimality. Cambridge: Cambridge University Press; 2001. p. 1-23.

Ospovat D. Perfect adaptation and teleological explanation: approaches to the problem of the history of life in the mid-nineteenth century. In: Coleman W, Limoges C, editors. Studies in history of biology. Baltimore: Johns Hopkins University Press; 1981a. p. 33-56.

Ospovat D. The development of Darwin's theory. Natural history, natural theology, and natural selection, 1838-1859. Cambridge: Cambridge University Press; 1981 b.

Owen R. On the archetype and homologies of the vertebrate skeleton. London: John van Voorst; 1848.

Palumbi S. The evolution explosion. New York: WW Norton; 2001.

Panchen AL. Classification, evolution, and the nature of biology. Cambridge: Cambridge University Press; 1994.

Pennock RT. Tower of Babel: the evidence against the new creationism. Cambridge: MIT Press; 1999.

People for the American Way Foundation. Evolution and creationism in public education: an in-depth reading of public opinion. Danbury: DYG; 2000.

Perloff J. Tornado in a junkyard. Burlington: Refuge Books; 1999.

Petto AJ, Mead LS. Homology: why we know a whale is not a fish. Evol Educ Outreach. 2009;2(4):617-21.

Pew Research Center. For Darwin Day, 6 facts about the evolution debate. http://www.pewresearch.org/fact-tank/2017/02/10/darwin-day/; 2017. Accessed 8 Dec 2017.

Prothero DR. Evolution: what the fossils say and why it matters. New York: Columbia University Press; 2007.
Radick G. Deviance, Darwinian-style [Review of the book Darwinian heresies, edited by A. Lustig, R.J. Richards \& M. Ruse]. Metascience. 2005;14:453-7.

Randall JH Jr. Nature and historical experience. New York: Columbia University Press; 1958.

Rankin RL. The comparative method. In: Joseph BD, Janda RD, editors. The handbook of historical linguistics. New York: Wiley; 2003. p. 199-212.

Rieppel O, Kearney M. The poverty of taxonomic characters. Biol Philos. 2007:22(1):95-113.

Rogers AR. The evidence for evolution. Chicago: University Chicago Press; 2011

Romanes GJ. The scientific evidences of organic evolution. London: Macmillan; 1882

Rosengren KS, Brem SK, Evans EM, Sinatra GM, editors. Evolution challenges: integrating research and practice in teaching and learning about evolution Oxford. UK: Oxford University Press; 2012.

Rudwick MJS. Earth's deep history: how it was discovered and why it matters. Chicago: University Chicago Press; 2014

Ruse M. The Darwinian revolution: science red in tooth and claw. Chicago: University Chicago Press; 1979.

Ruse M. Taking Darwin seriously. Oxford: Basil Blackwell; 1986.

Ruse M. Monad to man: the concept of progress in evolutionary biology. Cambridge: Harvard University Press; 1996.

Ruse M. Darwin and design: does evolution have a purpose. Cambridge: Harvard University Press; 2003.

Ruse M. Natural theology: the biological sciences. In: Manning RRE, editor. The Oxford handbook of natural theology. Oxford: Oxford University Press: 2013. p. 397-418.

Scott EC, Branch G. Don't call it "Darwinism". Evol Educ Outreach. 2010:2:90-4.

Senter P. Vestigial structures exist even within the creationist paradigm. Rep Natl Cent Sci Educ. 2010;30(4):18-26.

Shafer RJ. A guide to historical method (Revised ed.). Homewood: The Dorsey Press; 1974

Shanks N. God, the devil, and Darwin: a critique of intelligent design theory. Oxford: Oxford University Press; 2004.

Shellberg T. Teaching how to answer "why" questions about biology. Am Biol Teach. 2001;63:16-9.

Shtulman A. Qualitative differences between naïve and scientific theories of evolution. Cogn Psychol. 2006;52(2):170-94.

Shtulman A. Why people do not understand evolution. An analysis of the cognitive barriers to fully grasping the unity of life. Skeptic. 2011;16:2-6.

Shubin N, Tabin C, Carroll S. Deep homology and the origins of evolutionary novelty. Nature. 2009;457:818-23.

Sober E. Evidence and evolution: the logic behind the science. Cambridge: Cambridge University Press; 2008.

Spinney L. Remnants of evolution. N Sci. 2008;198:42-5.

Thagard P, Findlay S. Getting to Darwin: obstacles to accepting evolution by natural selection. Sci Educ. 2009;19(6-8):625-36.

Thanukos A. A look at linguistic evolution. Evol Educ Outreach. 2008a;1(3):281-6.

Thanukos A. Bringing homologies into focus. Evol Educ Outreach. 2008b;1(4):498-504.

Theobald DL. 29+ evidences for macroevolution: the scientific case for common descent. Talk Origins Archive. 2012. http://www.talkorigins.org/ fags/comdesc/. Accessed 16 Dec 2013.

Tylor EB. Primitive culture. 3rd ed. New York: Henry Holt; 1889.

Van Wyhe J. The descent of words: evolutionary thinking 1780-1880. Endeavour. 2005;29:94-100.

Vermeij GJ. The evolutionary world. How adaptation explains everything from seashells to civilization. New York: St Martin's Press: 2010

Vincent JM. Historical research: an outline of theory and practice. New York: Henry Holt; 1911

Vrba ES. Exaptation. In: Pagel M, editor. Encyclopedia of evolution. Oxford: Oxford University Press; 2002. p. 338-9.

Wagner G. Homology. In: Pagel M, editor. Encyclopedia of evolution. Oxford: Oxford University Press; 2002. p. 497-501.

Ward H. Evolution for John Doe. Indianapolis: Bobbs-Merrill; 1925.

Weiss KM, Kawasaki K. Reading the palimpsests of life: some relatives bear only the faintest trace of their ancestor. Evol Anthropol. 2006;15(6):207-11. 
Werth AJ. Vestiges of the natural history of development: historical holdovers reveal the dynamic interaction between ontogeny and phylogeny. Evol Educ Outreach. 2014;7:12
Wiedersheim W. The structure of man; An index to his past history (trans. by $\mathrm{H}$. \& M. Bernard). London: Macmillan; 1895.

Wise D."Intelligent"design versus evolution. Science. 2005;309:556-7.
Submit your manuscript to a SpringerOpen ${ }^{\circ}$ journal and benefit from:

- Convenient online submission

- Rigorous peer review

- Open access: articles freely available online

- High visibility within the field

- Retaining the copyright to your article

Submit your next manuscript at $\boldsymbol{\nabla}$ springeropen.com 